\title{
Yield of Italian ryegrass mixed with red clover and balansa clover
}

\author{
T.P. RYAN-SALTER and A.D. BLACK \\ Department of Agricultural Sciences, Lincoln University, Lincoln 7647, Christchurch
}

Alistair.Black@lincoln.ac.nz

\begin{abstract}
A mixture experiment was conducted at Lincoln University to investigate if mixtures of Italian ryegrass, red clover and balansa clover gave more high quality forage and suppressed weeds better than Italian ryegrass monocultures. Thirteen seed mixtures with varied species proportions were sown at 20 and $30 \mathrm{~kg} /$ ha in March 2011. The minimum amount of Italian ryegrass was $50 \%$ of the total sowing rate. Plots were harvested six times over 12 months and were neither irrigated nor fertilised. Inclusion of red clover increased yield by $41 \%$ compared with the Italian ryegrass

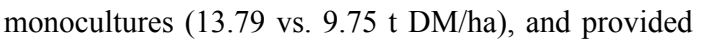
effective weed suppression $(<5 \%$ of total annual yield) and high quality forage $(17.5 \%$ crude protein, $11.3 \mathrm{MJ} /$ $\mathrm{kg}$ DM metabolisable energy). No benefits were gained from mixing balansa clover with Italian ryegrass. The optimum seed mixture was $12 \mathrm{~kg} / \mathrm{ha}$ of Italian ryegrass, $8 \mathrm{~kg} / \mathrm{ha}$ of red clover and no balansa clover.
\end{abstract}

Keywords: dryland, greenfeed mixtures, simplex design

\section{Introduction}

The annual pattern of pasture production on dryland farms necessitates supplementary greenfeed for grazing in winter and early spring, and over summer and autumn in drought prone areas. To help overcome these feed shortages, an emerging practice is to autumn sow a mixture of Italian ryegrass (Lolium multiflorum Lam.) and one or more short-lived legumes such as the perennial red clover (Trifolium pratense $\mathrm{L}$.) and balansa clover (Trifolium michelanium Savi), which is a semiprostrate annual.

The expectation is that these mixtures will produce more high quality forage and suppress weeds better than an Italian ryegrass monoculture. Furthermore, ecological theory suggests that the magnitude of the response would depend on the clover species (identity), number of species (richness) and species proportions (abundance) in the mixture (Connolly et al. 2009). Useful characteristics of each species include rapid establishment and winter/spring growth from Italian ryegrass (Brougham 1956), high quality forage from red clover during summer and the second autumn due to its deep taproots (Brown et al. 2003), and drought avoidance from balansa clover (Monks et al. 2008).
Nitrogen fixation is usually the main reason for planting legumes with grasses (Harris 2001).

The objectives of this study were 1) to investigate the effects of planting red clover and balansa clover with Italian ryegrass on the yield, quality and weed suppression of greenfeed, and 2) to formulate the optimum seed mixture of the three species. Specific questions were: 1) Can Italian ryegrass planted with clovers produce more high quality forage and suppress weeds better than Italian ryegrass in monoculture? 2) Do such benefits depend on the species of clover, number of clover species, and species proportions in the seed mixture? 3) Are the benefits consistent across sowing rates? 4) Can the benefits persist over time?

\section{Materials and methods}

Thirteen seed mixtures of 'Feast II' Italian ryegrass, 'Colenso' red clover and 'Bolta' balansa clover were created using a simplex mixture-amount design (Cornell 2002) and Minitab 16 Statistical Software. The mixtures varied in species proportions with the minimum proportion of Italian ryegrass constrained to $50 \%$ of the total sowing rate (Figure 1). There was one Italian ryegrass monoculture, six mixtures of Italian ryegrass and either red clover or balansa clover, and six three-species mixtures. Each mixture was sown at two sowing rates, 20 and $30 \mathrm{~kg} / \mathrm{ha}$, which were common for Italian ryegrass-based swards. The 26 mixture-amount combinations were assigned to plots $(2.1 \times 10 \mathrm{~m})$ in a randomised block design with three replicates.

The Italian ryegrass seed was treated with Superstrike, a treatment of insecticide and fungicide (PGG Wrightson Seeds, Kimihia, Christchurch). Balansa clover was inoculated with rhizobia by adding Group C ALOSCA ${ }^{\circledR}$ (ALOSCA Technologies Pty Ltd, Osborne Park, WA, Australia) with the seed at 10 $\mathrm{kg} / \mathrm{ha}$. Red clover did not require inoculation. Seed characteristics of each species are described in Table 1.

The experiment was conducted in a field (H13) at Lincoln University. The topography was flat and the soil type was a Templeton silt loam. Soil test results from January 2011 were: pH 6, Olsen P $17 \mathrm{mg} / \mathrm{L}, \mathrm{K}$ $0.56 \mathrm{me} / 100 \mathrm{~g}, \mathrm{Ca} 7.1 \mathrm{me} / 100 \mathrm{~g}, \mathrm{Mg} 1.08 \mathrm{me} / 100 \mathrm{~g}, \mathrm{Na}$ $0.14 \mathrm{me} / 100 \mathrm{~g}$ and sulphate $\mathrm{S} 1 \mathrm{mg} / \mathrm{kg}(7.5 \mathrm{~cm}$ depth$)$. Climate data are given in Table 2.

The field had been a perennial ryegrass (Lolium 
perenne L.)/white clover (Trifolium repens L.) pasture. In late February 2011 it was irrigated and sprayed with glyphosate to kill resident vegetation. Prior to sowing, it was ploughed, cultivated to produce a fine, firm seedbed, and fertilised with $250 \mathrm{~kg} / \mathrm{ha}$ of Sulphur Super $20(8.1 \%$ P, $20.5 \%$ S, $18 \%$ Ca). Plots were drilled on 10 March 2011 using an Ojyord cone seeder $(0.15 \mathrm{~m}$ row spacing, 10-15 mm sowing depth).

Plots were grazed with hoggets on 11 May and 19 July, cut on 18 October and 13 December to $4-5 \mathrm{~cm}$ residual height to simulate silage cuts, and grazed with hoggets again on 2 February and 30 March 2012. Sufficient sheep were used to graze the plots to $4-5$ $\mathrm{cm}$ residual height within 3-5 days. No irrigation or fertilisers were applied during the measurement period.

Total yield and botanical composition were measured before each grazing or cutting. A strip $(0.6 \times 10 \mathrm{~m})$ was cut to $4-5 \mathrm{~cm}$ height using a flail-type mower. The cut material was weighed and a subsample $(100 \mathrm{~g})$ was dried at $65^{\circ} \mathrm{C}$ for $48 \mathrm{~h}$ to determine the total dry matter (DM) yield. For botanical composition, a clip sample (10 random clips) was cut to $4-5 \mathrm{~cm}$ height and a subsample ( $c a .200 \mathrm{~g}$ ) was separated into sown species and weeds before drying at $65^{\circ} \mathrm{C}$.

Herbage samples were retained for determination of crude protein and metabolisable energy (ME) by near infrared reflectance spectroscopy (NIRS). Samples from five seed mixtures were selected for analysis based on the yield and botanical composition results: the Italian ryegrass monoculture, the three Italian ryegrass/red clover mixtures, and the 50:50 Italian ryegrass/balansa clover mixture, from each replicate and sowing rate.

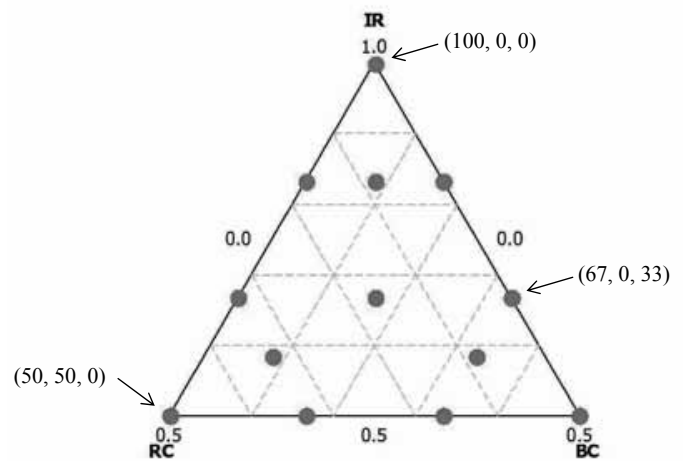

Figure 1. Diagram of the simplex mixture design with Italian ryegrass (IR), red clover $(\mathrm{RC})$ and balansa clover (BC). Each point in the triangle represents a seed mixture with its position determined by its species proportions (IR, RC, BC), e.g., (100, 0, 0) represents a monoculture of Italian ryegrass. The minimum proportion of Italian ryegrass was constrained to $50 \%$.

\section{Statistical analysis}

Significant $(\alpha=0.05)$ effects of seed mixture, sowing rate and their interaction were tested by ANOVA. Orthogonal contrasts were used to test for differences in yield between the Italian ryegrass monoculture (IR) and mixtures with red clover (IR/RC), balansa clover (IR/ $\mathrm{BC})$ and both clovers (IR/RC/BC). For forage quality, significant differences between mixture means were identified using Fisher's Least Significant Difference (LSD) test. The analyses were done in Genstat 14 software.

The effects of species proportions in the seed mixture on accumulated yield were analysed using the mixture

Table 1. Seed characteristics of 'Feast II' Italian ryegrass, 'Colenso' red clover and 'Bolta' balansa clover.

\begin{tabular}{lccc}
\hline Variable & Italian ryegrass & Red clover & Balansa clover \\
Thousand seed weight $(\mathrm{g})$ & 3.50 & 1.93 & 1.04 \\
Thousand seed volume $\left(\mathrm{cm}^{3}\right)$ & 8.4 & 2.3 & 1.2 \\
Germination \%† & 88 & 92 & 83 \\
Seeds sown per $\mathrm{m}^{2}$ at $1 \mathrm{~kg} / \mathrm{ha}$ & 29 & 52 & 96 \\
Cost $(\$ / \mathrm{kg})$ & 12.00 & 14.90 & 11.90 \\
\hline
\end{tabular}

†Three replicates of 50 seeds germinated at $20^{\circ} \mathrm{C}$ for 21 days.

Table 2. Monthly air temperature $\left({ }^{\circ} \mathrm{C}\right)$ and rainfall $(\mathrm{mm})$ between March 2011 and March 2012 with long-term (LT) means at Lincoln University.

\begin{tabular}{llllllllllllll}
\hline & Mar & Apr & May & Jun & Jul & Aug & Sep & Oct & Nov & Dec & Jan & Feb & Mar \\
\hline Temp. & 15.3 & 11.2 & 11.4 & 8.1 & 6.0 & 6.5 & 8.7 & 11.0 & 13.0 & 15.2 & 15.7 & 15.7 & 13.4 \\
Rain & 63 & 90 & 49 & 53 & 46 & 107 & 35 & 128 & 66 & 46 & 31 & 52 & 78 \\
LT Temp. & 15.1 & 12.3 & 9.7 & 6.9 & 6.0 & 7.8 & 10.1 & 11.1 & 13.5 & 15.3 & 16.7 & 16.5 & 15.1 \\
LT Rain & 33 & 59 & 88 & 66 & 63 & 78 & 41 & 57 & 53 & 63 & 48 & 39 & 33 \\
\hline
\end{tabular}


regression method in Minitab 16. A quadratic mixture model was fit to the data as follows:

$\mathrm{Y}=\mathrm{b}_{1} \mathrm{IR}+\mathrm{b}_{2} \mathrm{RC}+\mathrm{b}_{3} \mathrm{BC}+\mathrm{b}_{4} \mathrm{IR} * \mathrm{RC}+\mathrm{b}_{5} \mathrm{IR} * \mathrm{BC}$ $+\mathrm{b}_{6} \mathrm{RC} * \mathrm{BC}+\mathrm{b}_{7} \mathrm{IR} * \mathrm{SR}+\mathrm{b}_{8} \mathrm{RC} * \mathrm{SR}+\mathrm{b}_{9} \mathrm{BC} * \mathrm{SR}+$ $\mathrm{b}_{10} \mathrm{IR} * \mathrm{RC} * \mathrm{SR}+\mathrm{b}_{11} \mathrm{IR} * \mathrm{BC} * \mathrm{SR}+\mathrm{b}_{12} \mathrm{RC} * \mathrm{BC} * \mathrm{SR}+\varepsilon$

$\mathrm{Y}$ is the yield response from a mixture; IR, $\mathrm{RC}$ and $\mathrm{BC}$ are the sown proportions of Italian ryegrass, red clover and balansa clover respectively; and SR is the overall sowing rate (adjusted to -5 for $20 \mathrm{~kg} / \mathrm{ha}$ and 5 for 30 $\mathrm{kg} / \mathrm{ha}$ so the mean equals zero), $\mathrm{b}_{1}$ is an estimate of the response of the Italian ryegrass monoculture at average sowing rate, $b_{4}$ to $b_{6}$ represent the interaction effects for the combination of two species, $b_{7}$ to $b_{12}$ are interaction effects of species and amount, and $\varepsilon$ is a random error term assumed normally and independently distributed with mean zero and constant variance.

The quadratic mixture model was used to generate a contour plot of the predicted yields. The optimum species proportions in the seed mixture for maximum yield were estimated by response optimisation analysis in Minitab 16.

\section{Results}

\section{Total yield}

Italian ryegrass/red clover mixtures produced $41 \%$ more yield $(\mathrm{P}<0.001)$, accumulated over harvests (13.79 $\mathrm{t} \mathrm{DM} / \mathrm{ha})$, than the Italian ryegrass monocultures $(9.75 \mathrm{t} \mathrm{DM} / \mathrm{ha})$, which produced similar yields to the mixtures with balansa clover (9.70 t DM/ha), as shown in Table 3. Mixtures with both clovers yielded 35\% more $(\mathrm{P}<0.001)$ than the Italian ryegrass monocultures (13.15 t DM/ha). These effects were consistent over the December, February and March harvests. However, the Italian ryegrass monocultures produced $0.26 \mathrm{t} \mathrm{DM} / \mathrm{ha}$ more $(\mathrm{P}<0.05)$ than the average yield of all mixtures in May, while all mixtures gave similar yields to the monocultures in July and October.

There were no mixture-by-sowing rate interactions, indicating the mixture effects were consistent over sowing rates. The mixtures sown at $30 \mathrm{~kg} /$ ha produced on average $0.16 \mathrm{t} \mathrm{DM} / \mathrm{ha}$ more yield than those sown at $20 \mathrm{~kg} / \mathrm{ha}$ in May, July and March $(\mathrm{P}<0.001)$. However, accumulated yield after 12 months was not affected by overall sowing rate.

Table 3. Average total yield (t DM/ha) from seed mixtures with varied proportions of Italian ryegrass (IR), red clover (RC) and balansa clover $(\mathrm{BC})$ repeated at two overall sowing rates.

\begin{tabular}{|c|c|c|c|c|c|c|c|c|c|}
\hline \multicolumn{3}{|c|}{ Sown species (\%) } & \multicolumn{7}{|c|}{ Harvest } \\
\hline IR & $\mathrm{RC}$ & $\mathrm{BC}$ & 11 May & $19 \mathrm{Jul}$ & 18 Oct & $13 \mathrm{Dec}$ & $2 \mathrm{Feb}$ & $30 \mathrm{Mar}$ & $\begin{array}{l}\text { Accumu- } \\
\text { lated }\end{array}$ \\
\hline 100 & 0 & 0 & 0.81 & 0.81 & 4.07 & 2.87 & 0.90 & 0.28 & 9.75 \\
\hline 83 & 17 & 0 & 0.71 & 0.80 & 4.34 & 3.23 & 2.35 & 1.57 & 13.00 \\
\hline 67 & 33 & 0 & 0.74 & 0.79 & 4.23 & 3.47 & 2.89 & 2.03 & 14.15 \\
\hline 50 & 50 & 0 & 0.38 & 0.59 & 4.25 & 3.59 & 3.21 & 2.21 & 14.22 \\
\hline 83 & 0 & 17 & 0.76 & 0.84 & 3.74 & 2.88 & 0.88 & 0.37 & 9.46 \\
\hline 67 & 0 & 33 & 0.53 & 0.80 & 4.19 & 3.08 & 0.80 & 0.30 & 9.69 \\
\hline 50 & 0 & 50 & 0.45 & 0.73 & 4.38 & 3.06 & 0.93 & 0.41 & 9.95 \\
\hline 83 & 9 & 8 & 0.67 & 0.90 & 4.33 & 3.11 & 1.86 & 1.16 & 12.03 \\
\hline 58 & 9 & 33 & 0.54 & 0.73 & 4.05 & 3.15 & 1.97 & 1.38 & 11.82 \\
\hline 67 & 17 & 16 & 0.53 & 0.79 & 4.22 & 3.18 & 2.28 & 1.62 & 12.63 \\
\hline 50 & 17 & 33 & 0.47 & 0.66 & 4.22 & 3.37 & 2.69 & 1.93 & 13.34 \\
\hline 58 & 33 & 9 & 0.52 & 0.73 & 4.69 & 3.63 & 3.42 & 2.25 & 15.23 \\
\hline 50 & 33 & 17 & 0.40 & 0.71 & 4.14 & 3.43 & 3.08 & 2.12 & 13.88 \\
\hline SED & & & 0.120 & 0.097 & 0.210 & 0.183 & 0.259 & 0.183 & 0.548 \\
\hline IR $\vee$ II & & & $<0.05$ & NS & NS & $<0.001$ & $<0.001$ & $<0.001$ & $<0.001$ \\
\hline IR $\vee \mathrm{II}$ & & & $<0.05$ & NS & NS & NS & NS & NS & NS \\
\hline IR $\vee \mathrm{II}$ & $\mathrm{C} / \mathrm{BC}$ & & $<0.01$ & NS & NS & $<0.01$ & $<0.001$ & $<0.001$ & $<0.001$ \\
\hline \multicolumn{10}{|c|}{ Sowing rate } \\
\hline $20 \mathrm{~kg}$ & & & 0.50 & 0.68 & 4.24 & 3.26 & 2.09 & 1.27 & 12.03 \\
\hline $30 \mathrm{~kg}$ & & & 0.66 & 0.84 & 4.20 & 3.20 & 2.10 & 1.44 & 12.45 \\
\hline SED & & & 0.047 & 0.038 & 0.082 & 0.072 & 0.101 & 0.072 & 0.215 \\
\hline Signif & $\mathrm{ce}$ & & $<0.001$ & $<0.001$ & NS & NS & NS & $<0.05$ & NS \\
\hline
\end{tabular}




\section{Mixture model analysis}

The estimated coefficients of the mixture yield model are given in Table 4. None of the interaction terms involving the overall sowing rate (SR) were significant, indicating consistent mixture effects between 20 and 30 $\mathrm{kg} / \mathrm{ha}$, so these terms were removed from the model. Two species interaction terms were significant (IR*RC and $\mathrm{RC} * \mathrm{BC})$ and the mixture model was a good fit $\left(\mathrm{R}^{2}\right.$ $=0.83$ ).

The contour plot (Figure 2) shows how yield, predicted from the mixture model, increased as red clover replaced Italian ryegrass and balansa clover in the seed mixture, but including balansa clover with Italian ryegrass had no effect (the IR*BC coefficient was not significant, Table 4 ). The optimum seed mixture was estimated at about $60 \%$ Italian ryegrass, $40 \%$ red

Table 4. Estimated regression coefficients and their levels of significance for the quadratic mixture model of accumulated total yield ( $\mathrm{DM} / \mathrm{ha}$ ) as a function of the proportions of Italian ryegrass (IR), red clover $(\mathrm{RC})$ and balansa clover $(\mathrm{BC})$ in the seed mixtures.

\begin{tabular}{lcc}
\hline Term & Coefficients $(\mathrm{b})$ & Significance \\
$\mathrm{IR}$ & 9.77 & - \\
$\mathrm{RC}$ & 1.83 & - \\
$\mathrm{BC}$ & 12.09 & - \\
$\mathrm{IR}{ }^{\star} \mathrm{RC}$ & 33.29 & $<0.001$ \\
$\mathrm{IR}^{*} \mathrm{BC}$ & -3.65 & 0.570 \\
$\mathrm{RC}^{\star} \mathrm{BC}$ & 30.82 & $<0.001$ \\
$\mathrm{R}^{2}$ & 0.83 & \\
\hline
\end{tabular}

clover and no balansa clover. It gave the maximum predicted yield of $14.6 \mathrm{t} \mathrm{DM} / \mathrm{ha}$, which was $4.8 \mathrm{t} \mathrm{DM} /$ ha more than the predicted yield of the Italian ryegrass monoculture.

\section{Botanical composition}

Weeds accounted for $1-4 \%$ of the total yield across all treatments when averaged over harvests, indicating good weed suppression by all seed mixtures and the Italian ryegrass monocultures.

The species proportions in the sown species yield (total yield minus weed content) changed over time (Figure 3). Italian ryegrass contributed about $70-100 \%$ of the sown yield for the first three harvests, and red clover dominated most mixtures in February and March. Balansa clover contributed nearly $30 \%$ of sown yield in May and October, but was absent from all plots by February.

\section{Forage quality}

Forage crude protein was $1-2 \%$ higher $(\mathrm{P}<0.001)$ for the Italian ryegrass/red clover mixtures than the Italian ryegrass monocultures and the 50:50 Italian ryegrass/ balansa clover mixture in December and averaged over harvests (Table 5). Metabolisable energy was generally similar across all treatments. Forage quality was not affected by overall sowing rate.

\section{Discussion}

The Italian ryegrass mixed with clovers produced more yield than the Italian ryegrass in monoculture (Table 3)

Table 5. Average forage crude protein and metabolisable energy of the Italian ryegrass monoculture (IR), three Italian ryegrass/ red clover $(\mathrm{RC})$ mixtures, and the 50:50 Italian ryegrass/balansa clover $(\mathrm{BC})$ mixture. Means with different superscripts are significantly different $(a=0.05)$.

\begin{tabular}{|c|c|c|c|c|c|c|c|c|c|}
\hline \multicolumn{3}{|c|}{ Sown species (\%) } & \multicolumn{7}{|c|}{ Harvest } \\
\hline IR & $\mathrm{RC}$ & $\mathrm{BC}$ & 11 May & $19 \mathrm{Jul}$ & 18 Oct & $13 \mathrm{Dec}$ & $2 \mathrm{Feb}$ & $30 \mathrm{Mar}$ & Average \\
\hline & & & \multicolumn{7}{|c|}{ Crude protein (\%) } \\
\hline 100 & 0 & 0 & 28.7 & 24.3 & 9.0 & $5.5^{c}$ & 9.6 & 14.3 & $15.4^{b}$ \\
\hline 83 & 17 & 0 & 28.6 & 23.0 & - & $6.7^{\mathrm{b}}$ & 13.2 & 17.8 & $17.9^{a}$ \\
\hline 67 & 33 & 0 & 29.2 & 23.3 & - & $7.0^{\mathrm{b}}$ & 10.7 & 17.4 & $17.5^{\mathrm{a}}$ \\
\hline 50 & 50 & 0 & 30.2 & 25.0 & 9.2 & $8.0^{\mathrm{a}}$ & 10.7 & 18.2 & $17.0^{\mathrm{a}}$ \\
\hline 50 & 0 & 50 & 30.5 & 24.5 & 9.8 & $5.7^{c}$ & 10.0 & 14.1 & $16.0^{\mathrm{b}}$ \\
\hline SED & & & 0.83 & 0.93 & 0.51 & 0.42 & 1.97 & 1.91 & 0.46 \\
\hline \multicolumn{3}{|c|}{ Significance } & NS & NS & NS & $<0.001$ & NS & NS & $<0.001$ \\
\hline & & & \multicolumn{7}{|c|}{ Metabolisable energy (MJ/kg DM) } \\
\hline 100 & 0 & 0 & 11.7 & 12.7 & 12.2 & $11.3^{\mathrm{a}}$ & 9.5 & 10.9 & 11.4 \\
\hline 83 & 17 & 0 & 11.7 & 12.9 & - & $11.0^{\mathrm{ab}}$ & 9.9 & 10.7 & 11.3 \\
\hline 67 & 33 & 0 & 11.7 & 13.0 & - & $11.0^{\mathrm{ab}}$ & 9.6 & 10.5 & 11.2 \\
\hline 50 & 50 & 0 & 11.7 & 13.1 & 12.0 & $10.8^{\mathrm{b}}$ & 9.5 & 10.9 & 11.3 \\
\hline 50 & 0 & 50 & 11.7 & 13.1 & 12.0 & $10.8^{b}$ & 9.4 & 10.9 & 11.3 \\
\hline SED & & & 0.06 & 0.15 & 0.14 & 0.15 & 0.22 & 0.24 & 0.08 \\
\hline Signif & nce & & NS & NS & NS & $<0.05$ & NS & NS & NS \\
\hline
\end{tabular}




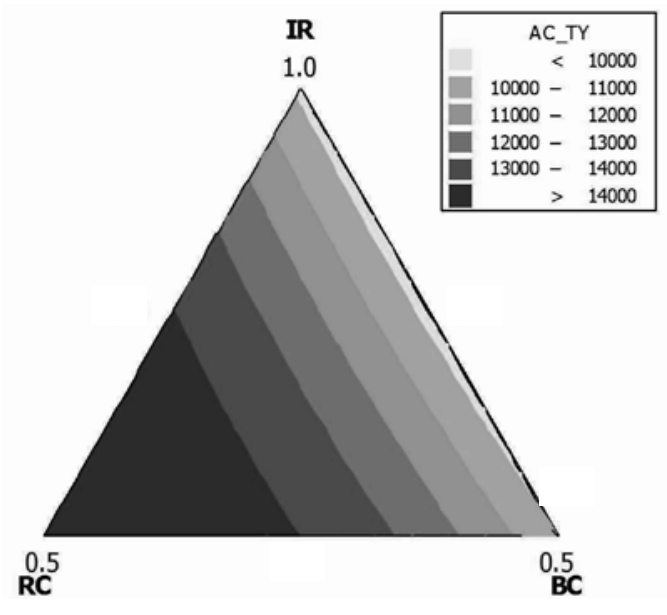

Figure 2. Contour plot of the relationship between accumulated total yield ( $\mathrm{kg} \mathrm{DM} / \mathrm{ha}$ ) and the proportions of Italian ryegrass (IR), red clover (RC) and balansa clover (BC) in the seed mixtures.

and provided effective weed suppression ( $1-4 \%$ weeds) and high quality forage (Table 5) after 12 months. However, the strength of these benefits depended on the composition of the seed mixture, particularly the species of clover used and their relative abundance (Figure 2).

The greatest yield benefits were gained from the combinations of red clover and Italian ryegrass (Table $3)$. There was also some evidence that these mixtures had higher crude protein contents (Table 5) than the Italian ryegrass monocultures, although these results were less compelling. The yield difference was about 4 t DM/ha after 12 months. Assuming a return of $20 \mathrm{c} / \mathrm{kg}$ DM (Thomson \& Muir 2009), this is about $\$ 800 /$ ha of extra feed gained from replacing some Italian ryegrass with red clover in the seed mix at the same overall sowing rate. In contrast, the lack of any significant effects of balansa clover suggests that its inclusion in the seed mix was not necessary.

Possible explanations for the agronomic benefits of the Italian ryegrass/red clover mixtures over the monoculture include: an ability to source both soil mineral N and biologically-fixed N (Harris 2001), complementary growth patterns between the two species (Harris 2001), greater access to soil moisture (Brown et al. 2003) and more efficient water-use (Moot et al. 2008), rapid establishment of both species (Moot et al. 2000), adaptation to lax grazing and cutting (Hay \& Ryan 1989), and greater light capture (Black et al. 2009). Any potential issues concerning treading damage and over-grazing of the Italian ryegrass/red clover mixtures were avoided by grazing the plots with sufficient sheep for short durations of 3-5 days when soil conditions were suitable.
The lower yields from the balansa clover mixtures can also be explained. Balansa clover established well and was most productive in spring (Figure 3). However, balansa is a top-flowering annual, meaning its reproductive stems were harvested in October and December, and any surviving plants would have reached the end of their lifecycle before the February harvest. Also, its seasonal growth pattern almost paralleled that of Italian ryegrass, so both species were in direct competition for most of their lifecycles, whereas red clover is winter dormant and most productive in summer when Italian ryegrass is less competitive. Other research has shown that balansa clover was productive in early to late spring in monocultures (Hyslop et al. 2003) and cockfoot (Dactylis glomerata L.) swards (Mills et al. 2008). In permanent swards balansa clover should be spelled in late spring-summer to set seed and re-establish in the second autumn (Monks et al. 2008).

The consistent mixture effects across sowing rates show that the blending properties of the three species were not confounded by density between 20 and 30 $\mathrm{kg} / \mathrm{ha}$. The small gains in yield from the high sowing rate in autumn and winter, but similar accumulated yields after 12 months (Table 3), were consistent with previous studies (Culleton \& Murphy 1987; Hay \& Ryan 1977). The minimum proportion of Italian ryegrass was constrained to $50 \%$ based on previous research (Brougham 1954). The seed mixtures with $50 \%$ Italian ryegrass $(10-15 \mathrm{~kg} / \mathrm{ha})$ produced about $0.1-0.4 \mathrm{t} \mathrm{DM} / \mathrm{ha}$ less than monocultures $(20-30 \mathrm{~kg} / \mathrm{ha})$ in the first autumn and winter, but nearly $4.5 \mathrm{t} \mathrm{DM} / \mathrm{ha}$ more after 12 months when sown with red clover (Table $3)$. The lack of any substantial differences between overall sowing rates means that the Italian ryegrass/red clover mix can be sown at $20 \mathrm{~kg} / \mathrm{ha}$.

The yield benefits from mixing Italian ryegrass and red clover were not consistent over harvests (Table 3 ) because the botanical composition of the swards changed seasonally (Figure 3). All mixtures yielded less than the monoculture in May because the clovers were slower to establish than Italian ryegrass (Brougham 1956; Moot et al. 2000), but they gave similar yields in July and October. Italian ryegrass contributed most of the forage at these times, followed by an increase in clover content, particularly red clover. Therefore, Italian ryegrass mixed with red clover is likely to increase total yield during summer and the second autumn without compromising yield during winter and early spring.

The mixture model quantified the effects of the seed mixtures on accumulated yield (Figure 2, Table 4) and defined the "optimum" seed mix for maximum yield (60\% Italian ryegrass, $40 \%$ red clover and no balansa clover). When sown at $20 \mathrm{~kg} / \mathrm{ha}$ this seed mix was predicted to produce $4.8 \mathrm{t} \mathrm{DM} / \mathrm{ha}$ more than straight 

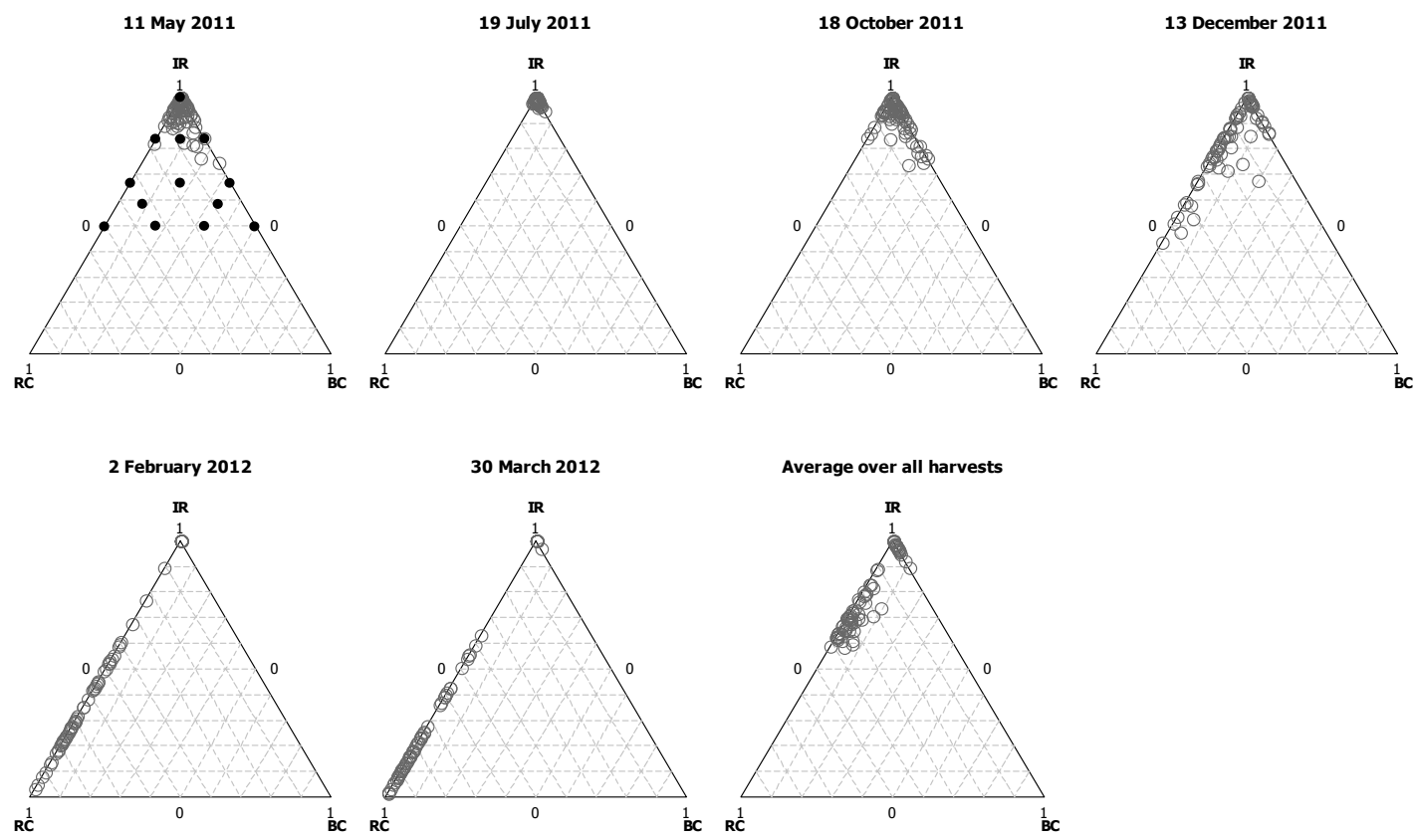

Figure 3. Changes in proportions of Italian ryegrass (IR), red clover (RC) and balansa clover (BC) in the sown species yield (total yield minus weed content) from each plot $(n=78)$ over harvests and compared with the composition of the seed mixtures (black symbols).

Italian ryegrass for an additional seed cost of $\$ 23 / \mathrm{ha}$ (Table 1). This equates to $208 \mathrm{~kg} \mathrm{DM}$ for each extra dollar spent on seed. However, when sown at $30 \mathrm{~kg} / \mathrm{ha}$ the margin was lower $(138 \mathrm{~kg} \mathrm{DM} / \$)$ because sowing rate did not affect yield (Table 3 ) and the extra seed cost was $\$ 34.80 / \mathrm{ha}$. Regardless of sowing rate, these seed costs were less than the value of the extra feed produced (\$960/ha at 20c/kg DM).

The optimum seed mix in our study had less Italian ryegrass and more red clover than most commercial seed mixtures, which often contain about $20 \mathrm{~kg} / \mathrm{ha}$ Italian ryegrass, $4 \mathrm{~kg} / \mathrm{ha}$ red clover and $3 \mathrm{~kg} / \mathrm{ha}$ white clover, i.e. $74 \%: 15 \%: 11 \%$. Assuming balansa clover was used instead of white clover under the same growing conditions as our study, the accumulated yield expected from this mix would be about $12.7 \mathrm{t} \mathrm{DM} /$ ha based on our yield model. This was about $1.9 \mathrm{t} \mathrm{DM} /$ ha less than the yield predicted from 12 and $8 \mathrm{~kg} / \mathrm{ha}$ Italian ryegrass and red clover, and the seed cost was $\$ 72 /$ ha more.

\section{Conclusions}

Italian ryegrass mixed with red clover gave $41 \%$ more yield than Italian ryegrass in monoculture as well as effective weed suppression and high quality forage.

There were no agronomic benefits from mixing balansa clover with Italian ryegrass under the lax grazing/cutting regime imposed.

Italian ryegrass/red clover mixing effects were robust across overall sowing rates of 20 and $30 \mathrm{~kg} / \mathrm{ha}$.

The optimum seed mixture was $12 \mathrm{~kg} / \mathrm{ha}$ Italian ryegrass, $8 \mathrm{~kg} / \mathrm{ha}$ red clover and no balansa clover.

\section{ACKNOWLEDGEMENTS}

We thank Dave Jack and Dan Dash for technical assistance.

\section{REFERENCES}

Black, A.D.; Laidlaw, A.S.; Moot, D.J.; O'Kiely, P. 2009. Comparative growth and management of white and red clovers. Irish Journal of Agricultural and Food Research 33: 33-50.

Brougham, R.W. 1954. Pasture establishment studies I. The effect of grass seeding rate on the establishment and development of pastures of short rotation ryegrass, red and white clovers. New Zealand Journal of Science and Technology A35: 518-538.

Brougham, R.W. 1956. The rate of growth of shortrotation ryegrass pastures in the late autumn, winter, and early spring. New Zealand Journal of Science and Technology A38: 78-87.

Brown, H.E.; Moot, D.J.; Pollock, K.M. 2003. Long term growth rates and water extraction patterns of dryland chicory, lucerne and red clover. Legumes for dryland pastures. Grassland Research and Practice Series 11: 91-99.

Connolly, J.; Finn, J.A.; Black, A.D.; Kirwan, L.; 
Brophy, C.; Lüscher, A. 2009. Effects of multi-species swards on dry matter production and the incidence of unsown species at three Irish sites. Irish Journal of Agricultural and Food Research 48: 243-260.

Cornell, J.A. 2002. Experiments with mixtures: Designs, models, and the analysis of mixture data. 3rd Edition. Wiley, Chichester. 305 pp.

Culleton, N.; Murphy, W.E. 1987. Effects of seeding rates and of mixtures of Lolium multiflorum Lam. and Lolium perenne L. on productivity. Irish Journal of Agricultural Research 26: 93-104.

Harris, W. 2001. Formulation of pasture seed mixtures with reference to competition and succession in pastures. pp. 149-174. In: Competition and succession in pastures. Eds. Tow, P.G.; Lazenby, A. CABI, Wallingford, Oxfordshire, UK.

Hay, R.J.M.; Ryan, D.L. 1977. Effect of seeding rate on yield distribution of Tama/Rahu greenfeed at two sites in Southland. Proceedings of the New Zealand Grassland Association 39: 165-173.

Hay, R.J.M.; Ryan, D.L. 1989. A review of 10 years' research with red clovers under grazing in Southland. Proceedings of the New Zealand Grassland Association 50: 181-187.

Hyslop, M.G.; Slay, M.W.A.; Moffat, C.A. 2003. Dry matter accumulation and sheep grazing preference of six winter active annual legumes. Legumes for dryland pastures. Grassland Research and Practice Series 11: 117-122.
Mills, A.; Smith, M.C.; Lucas, R.J.; Moot, D.J. 2008. Dryland pasture yields and botanical composition over 5 years under sheep grazing in Canterbury. Proceedings of the New Zealand Grassland Association 70: 37-44.

Monks, D.P.; Moot, D.J.; Smith, M.C.; Lucas, R.J. 2008. Grazing management for regeneration of balansa clover in a cocksfoot pasture. Proceedings of the New Zealand Grassland Association 70: 233-238.

Moot, D.J.; Scott, W.R.; Roy, A.M.; Nicholls, A.C. 2000. Base temperature and thermal time requirements for germination and emergence of temperate pasture species. New Zealand Journal of Agricultural Research 43: 15-25.

Moot, D.J.; Brown, H.E.; Pollock, K.M.; Mills, A. 2008. Yield and water use of temperate pastures in summer dry environments. Proceedings of the New Zealand Grassland Association 70: 51-57.

Thomson, B.C.; Muir, P.D. 2009. Lamb growth rate on annual and perennial ryegrasses. Proceedings of the New Zealand Grassland Association 71: 207-210. 
